\title{
Naturally occurring radioactivity in some Swedish concretes and their constituents - Assessment by using I-index and dose-model
}

\author{
M. Döse ${ }^{\text {a, * }}$, J. Silfwerbrand ${ }^{b}$, C. Jelinek ${ }^{c}$, J. Trägårdh $^{\mathrm{d}}$, M. Isaksson ${ }^{\mathrm{e}}$ \\ a Swedish Cement and Concrete Research Institute (CBI), c/o SP, Box 857, SE-501 15 Borås, Sweden \\ ${ }^{\mathrm{b}}$ Royal Institute of Technology (KTH), Department of Civil and Architectural Engineering, Brinellvägen 23, SE-100 44 Stockholm, Sweden

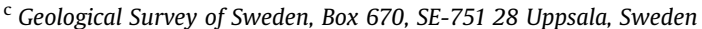 \\ ' Swedish Cement and Concrete Research Institute (CBI), Drottning Kristinas väg 26, SE-100 44 Stockholm, Sweden \\ e University of Gothenburg, Institute of Clinical Science, Department of Radiation Physics, Gula Stråket 2B, Sahlgrenska University Hospital, SE-413 45, \\ Göteborg, Sweden
}

\section{A R T I C L E I N F O}

\section{Article history:}

Received 13 October 2015

Received in revised form

5 February 2016

Accepted 13 February 2016

Available online $\mathrm{xxx}$

\section{Keywords:}

Aggregates

Building materials

Concrete

Construction product

Dose model

I-index

Radioactivity

\begin{abstract}
A B S T R A C T
The reference level for effective dose due to gamma radiation from building materials and construction products used for dwellings is set to $1 \mathrm{mSv}$ per year (EC, 1996, 1999), (CE, 2014). Given the specific conditions presented by the EC in report 112 (1999) considering building and construction materials, an I-index of 1 may generate an effective dose of $1 \mathrm{mSv}$ per year. This paper presents a comparison of the activity concentrations of ${ }^{40} \mathrm{~K},{ }^{226} \mathrm{Ra}$ and ${ }^{232} \mathrm{Th}$ of aggregates and when these aggregates constitute a part of concrete. The activity concentration assessment tool for building and construction materials, the Iindex, introduced by the EC in 1996, is used in the comparison. A comparison of the I-indices values are also made with a recently presented dose model by Hoffman (2014), where density variations of the construction material and thickness of the construction walls within the building are considered. There was a $\sim 16-19 \%$ lower activity index in concretes than in the corresponding aggregates. The model by Hoffman further implies that the differences between the I-indices of aggregates and the concretes' final effective doses are even larger. The difference is due, mainly to a dilution effect of the added cement with low levels of natural radioisotopes, but also to a different and slightly higher subtracted background value (terrestrial value) used in the modeled calculation of the revised I-index by Hoffman (2014). Only very minimal contributions to the annual dose could be related to the water and additives used, due to their very low content of radionuclides reported.
\end{abstract}

() 2016 Elsevier Ltd. All rights reserved.

\section{Introduction and background}

\subsection{European regulations and directives}

The European Commission (2014) recently declared, through the implementation of the EU's Basic Safety Standard (BSS), a reference level for dose from gamma radiation in building materials from the natural radioisotopes ${ }^{40} \mathrm{~K},{ }^{226} \mathrm{Ra}\left({ }^{238} \mathrm{U}\right)$ and ${ }^{232} \mathrm{Th}$. The Construction Product Regulation, CPR (CE, 2011) views the building materials as construction products, including materials such as concrete. Hence, a construction product can have several

\footnotetext{
* Corresponding author.

E-mail addresses: magnus.dose@cbi.se (M. Döse), jsilfwer@kth.se (J. Silfwerbrand), cecilia.jelinek@sgu.se (C. Jelinek), jan.tragardh@cbi.se (J. Trägårdh), mats.isaksson@radfys.gu.se (M. Isaksson).
}

constituents of different building materials. It is also clearly defined within the CPR that it is the construction product as put on the market that has to fulfill the requirements set out by the regulations and directives. Thus, within this article, the word building material is predominantly used for each constituent, such as cement, water or aggregate which make up the construction product, concrete.

In 1999, the European commission put forward a conceptual model (EC, 1999) for the calculation of the indicative dose to the human body by use of the I-index. ${ }^{1}$ The model is a refinement of earlier works of ionizing radiation in relation to building materials

\footnotetext{
${ }^{1}$ The I-index is calculated by the known activity concentration $(\mathrm{Bq} / \mathrm{kg})$ of the elements ${ }^{40} \mathrm{~K},{ }^{226} \mathrm{Ra}$ and ${ }^{232} \mathrm{Th}$ in the construction product. $\mathrm{I}=\mathrm{C}_{40 \mathrm{~K}} / 3000 \mathrm{~Bq} /$ $\mathrm{kg}+\mathrm{C}_{226 \mathrm{Ra}} / 300 \mathrm{~Bq} / \mathrm{kg}+\mathrm{C}_{232 \mathrm{Th}} / 20 \mathrm{~Bq} / \mathrm{kg}$, where $\mathrm{C}_{40 \mathrm{~K}}, \mathrm{C}_{226 \mathrm{Ra}}$ and $\mathrm{C}_{232 \mathrm{Th}}$ are the activity concentrations for each element. The I-Index lacks unit.
} 
presented by, for example, Krisiuk et al. (1971), Stranden (1976) and Beretka and Matthews (1985), but also taking into account some geometrical arrangements and thickness of walls as presented by Koblinger (1978). The calculations using the Berger Model for attenuation and build up was defined by Markkanen (1995), which serves as a basis for the European model (EC, 1996, 1999). The model is, as of today, also validated through Monte-Carlo simulation and presented by the European technical commission-CEN-TC 351-Release of dangerous substances - as a Technical report, 2014 (Draft TR 00351020 Dose assessment of emitted gamma radiation, 2014). Complementing this proposed I-index is a dose model (Hoffman, 2014), ${ }^{2}$ which also takes into account the thickness and density aspects of the material. However, the dose model is still a simplified tool, where all walls, floor and roof within the room are fixed with an equal size, the same concrete material and cannot be varied individually (model room $3 \mathrm{~m} \times 4 \mathrm{~m} \times 2.5 \mathrm{~m}$ without doors or windows). If several construction products are used to build up the final housing wall, e. g concrete walls and tiles, a more sophisticated dose model such as presented by Markkanen (1995) ought to be used. It should also be addressed that different authors have presented different models to calculate the effective dose inside a room (Koblinger, 1978; Markkanen, 1995; Stoulos et al., 2003; Maringer et al., 2013; Nuccetelli et al., 2015). Beside these different models to evaluate the effective dose within a room, many assessment tools have evolved on a national scale (Trevisi et al., 2013).

In the 2013/59/EURATOM directive (CE, 2014) it is stated that "The activity concentration index value of 1 can be used as a conservative screening tool for identifying materials that may cause the reference level laid down in Article 75 to be exceeded". It is thus important for both producers of building materials, contractors, clients, and regulators, to understand the link between the I-index of building materials and the resulting effective dose from the buildings. This will help concrete producers and contractors to optimize e.g. aggregate mixes for concrete, so as to get a final construction material that will not cause an effective dose over the reference value.

Theoretically, the finalized concrete product activity concentrations of ${ }^{40} \mathrm{~K},{ }^{226} \mathrm{Ra}$ and ${ }^{232} \mathrm{Th}(\mathrm{Bq} / \mathrm{kg})$ shall be the sum of every constituent making up the concrete product (Draft TS 00351014, 2012; CE, 2014).

\subsection{Previous Swedish and European studies}

Swedish limestone used for cement-clinker production has in general a low content of the natural radionuclides in contrast to some of the aggregates used (Möre, 1985). Especially the granitoids (Hagberg and Möre, 1978; Mjönes, 1986; Möre, 1985) sometimes contains substantial amounts of ${ }^{40} \mathrm{~K},{ }^{226} \mathrm{Ra}$ and ${ }^{232} \mathrm{Th}$. Initial investigations by the Swedish Cement and Concrete Research Institute (CBI) in 2011 also showed that the radiation from the natural radioisotopes from a concrete specimen was substantially lower than that from aggregates constituting the concrete mix. The major components (in mass percent) of precast concrete products and cast-in-place concrete are the building materials; cement and aggregates, that together roughly make up $90-95 \%$ of the concrete in mass.

\footnotetext{
2 The dose model by Hoffman is calculated as effective dose rate, $\mathrm{D}$ (mSv/year). $\mathrm{D}=\left[\left[\left(281+16.3 \rho \mathrm{d}-0.0161(\rho \mathrm{d})^{2}\right] \times \mathrm{C}_{\mathrm{Ra}}+[319+18.5 \rho \mathrm{d}-\right.\right.$ $\left.\left.0.0178(\rho \mathrm{d})^{2}\right] \times \mathrm{C}_{\mathrm{Th}}+\left[22.3+128 \rho \mathrm{d}-0.00114(\rho \mathrm{d})^{2}\right] \times \mathrm{C}_{\mathrm{K}}\right] \times 10^{-6}-0.29 \mathrm{mSv}$, where density $(\rho)$ is in $\mathrm{kg} / \mathrm{m}^{3}$, thickness (d) in meters and activity concentration of each element $\left(\mathrm{C}_{\mathrm{Ra}}, \mathrm{C}_{\mathrm{Th}}, \mathrm{C}_{\mathrm{K}}\right)$ are in $\mathrm{Bq} / \mathrm{kg}$. The background value of $-0.29 \mathrm{mSv}$ corresponds to $60 \mathrm{nGy} / \mathrm{h}$ in absorbed dose as an European average.
}

A European study, collecting available references of natural radiation in construction products (Trevisi et al., 2012), presented some data of concrete structures in Sweden. Out of nearly five hundred concrete samples investigated, almost ninety (18\%) yielded an I-index $>1$. These data are however not fully representative for the crushed aggregates used today, due to the older use of aerated concrete (blue concrete) containing alum shale, rich in uranium, which was produced extensively between the years 1930 and 1975. Nonetheless, similar figures are reported by Andersson et al. (2007) which confirm the data presented by Trevisi et al. (2012).

Only a few studies on the annual dose (personal dose equivalent) from construction/building materials have been conducted in recent years within Sweden. According to ICRP (ICRP, 2007), the protection quantity, such as effective dose, cannot be measured in practice. However it can be justified, by measuring the operational quantity, personal dose equivalent, $\mathrm{Hp}(\mathrm{d})$ for individuals. The operational quantity for individual monitoring, meaning personal dose equivalent, is for protection purposes considered a sufficiently precise assessment of the effective dose (ICRP, 2007).

Recent studies on radiation doses to humans within dwellings have been produced by Erlandsson and Isaksson (2006) and Almgren et al. (2008). Erlandsson and Isaksson (2006) performed a multifold study within the cities of Gävle, Lund and Gothenburg due to the Chernobyl accident and deposition of ${ }^{137} \mathrm{Cs}$. As part of the study a comprehensive survey of the personal dose due to building materials was also conducted in Gothenburg. Twenty-five participants wore gamma dosimeters (Thermoluminescent dosimeters, $\mathrm{LiF}$ ) for eight weeks. The results indicated that in four out of nineteen $(\sim 20 \%)$ situations, the dosimeters, worn by the persons, showed an annual dose $>1 \mathrm{mSv}$ per year $(\sim 0.175-0.258 \mu \mathrm{Sv} / \mathrm{h})$. However, these readings also included the time spent by the participants outside the buildings/homes and thus could be seen as an overall mean, comprising both indoor and outdoor irradiation. Some dosimeters, that were stationary within the dwellings showed values exceeding $0.3 \mu \mathrm{Sv} / \mathrm{h}(\sim 2.6 \mathrm{mSv}$ per year $)$.

Almgren et al. (2008) reported comparative results between the areas of Gothenburg and Mark municipalities. A similar set-up, using both gamma dosimeters, where people wear the devices attached to the bodies as well as stationary dosimeters within the dwellings were used. Forty people from each region wrote diaries to record their time spent indoors and outdoors. In the Gothenburg region, approximately $87 \%$ of the time was spent indoors and $65 \%$ spent within the home. In the Mark region, $79 \%$ was spent indoors and $64 \%$ within the home. The results reveal that in only two out of 43 subjects ( 10\%), the personal- and dwelling dose rates exceeded $0.13 \mu \mathrm{Sv} / \mathrm{h}$ ( $1.1 \mathrm{mSv}$ per year). In view of the fraction of time spent indoors these measurements give a realistic approach to the annual dose rates exerted to the people. Both studies reported averages well below $1 \mathrm{mSv}$ per year in personal dose $(0.077 \mu \mathrm{Sv} / \mathrm{h}-$ Erlandsson \& Isaksson and $0.067 \mu \mathrm{Sv} / \mathrm{h}$ - Almgren et al.). The alphaemitter radon and its contribution to the personal dose have been shown to be negligible in the previous investigations.

\subsection{Aim of current study}

The Swedish Cement and Concrete Research Institute (CBI) has observed a significant difference in natural radioactivity between the aggregate and the finalized concrete containing the same aggregate The objective of this paper is to clarify the differences in ionizing radiation of gamma emissions between the raw material (aggregates) and the finalized product concrete, when presented as I-index and as annual effective dose in $\mathrm{mSv}$, according to the more precise dose model by Hoffman (2014). Thus, the article also focuses on the input of each constituent of the concrete and its 
implication to the final calculated I-index and effective dose.

The aggregates and concrete specimens/samples results reported in this study were also assessed in line with the suggested approach by the TC 351/WG 3/TG 31 group and its proposed draft; TS 00351014 Construction products - Assessment of release of dangerous substances - Determination of activity concentrations of radium-226, thorium-232 and potassium-40 in construction products using gamma-ray spectrometry (2012), which is currently under validation.

The study has primarily focused one the evaluation of crushed bedrock. In only one case, a glaciofluvials sand was used in the concrete mix. The selection of the different crushed bedrock types represents a variety of different aggregates produced in the central parts of Sweden, mainly the areas around the major cities Stockholm and Gothenburg.

\section{Methodology}

\subsection{Laboratory gamma spectrometric analyses (STUK)}

The methodology to compare different products, such as aggregates, cement and concrete was based on the laboratory analytical procedure described in Draft TS 00351014 (2012), using gamma-spectrometry to analyze activity concentrations of naturally occurring radionuclides. The Swedish Cement and Concrete Research Institute (CBI) has consulted the Radiation and Nuclear Safety Authority of Finland (STUK) that uses this methodology (Klemola et al., 2010) as an accredited test method.

The gamma energies for assessing the three radioactive nuclides were for ${ }^{40} \mathrm{~K}-1460.8 \mathrm{keV},{ }^{226} \mathrm{Ra}-186.2 \mathrm{keV}$ (contribution of Uranium-235 subtracted) and for ${ }^{232} \mathrm{Th}$, the decay of ${ }^{228} \mathrm{Ac}$ at $911.2 \mathrm{keV}$. The activity concentrations of gamma-emitting nuclides were measured with low-background, high-resolution High Purity Germanium (HPGe) spectrometers. In the investigation, mainly two different detectors were used. The detectors were placed in cylindrical background shields made of $120-140 \mathrm{~mm}$ thick lead. The shields were lined inside with cadmium and copper. The measured energy range was $30-2700 \mathrm{keV}$. The relative efficiency of the detectors varied from 37 to $90 \%$ and energy resolution between $1.6 \mathrm{keV}$ and $2.1 \mathrm{keV}$ at $1.33 \mathrm{MeV}$. The samples were measured either in $35 \mathrm{~mL}$ or $105 \mathrm{~mL}$ cylindrical beakers, or in $500 \mathrm{~mL}$ standard Marinelli beakers. The correction for sample height and density, as well as the effect of true coincidence summing, was taken into account in the calculation of the results. The uncertainties include both statistical uncertainty and uncertainty due to the efficiency calibration. The uncertainty of results, $2 \sigma$ (95\% confidence interval), determined from a mean value of all calculations is approximately $8-10 \%$, irrespectively of the energy being measured (from ${ }^{40} \mathrm{~K}$, ${ }^{226} \mathrm{Ra}$ or ${ }^{232} \mathrm{Th}$ ).

\subsection{Initial conditions and sampling procedure of aggregates and concrete}

In order to have similar conditions and to achieve good workability of the concrete, a reference aggregate sieve curve prescribed in SS-EN 1766 was used as a template before finalizing the concrete recipe (Table 1 ). Consequently, the particle size fractions (in weight $\%$ ) of the aggregates (for example $0-4 \mathrm{~mm}, 0-8 \mathrm{~mm}$ and $8-16 \mathrm{~mm}$ particle size fractions) between the different concrete recipes were similar.

The initial sampling of delivered aggregates was made according to the Swedish standard, SS-EN 932-1 (1997). A total weight of approximately $30 \mathrm{~kg}$ for each particle size fraction was selected and blended (weight \%) according to the prescribed sieve curve, SS-EN 1766 (2000). For analysis, the blended aggregates were then crushed in a cone crusher yielding particle size fractions of 0-6 mm. Finally, in order to reduce the sample size, a rotational splitter (SS-EN 932-2, 1999) was used. Between 6 and $8 \mathrm{~kg}$ was sent for gamma spectrometric analysis. The aggregate mixtures are denoted $\mathbf{A}_{\text {mix }}$ in the results (Table 2 ).

In a few cases a different procedure was used. For concrete specimens with Id-numbers 1,8 and 12 , each aggregate particle size fraction was analyzed. Thus, $30 \mathrm{~kg}$ of each particle size fraction was collected. The procedures to crush, homogenize and reduce the sample size were the same as for the aggregate mixtures. Consequently, the final activity concentrations of ${ }^{40} \mathrm{~K},{ }^{226} \mathrm{Ra}$ and ${ }^{232} \mathrm{Th}$ of the blended aggregates (for example $0-8 \mathrm{~mm}$ and $8-16 \mathrm{~mm}$ ) were calculated knowing each particle size fraction activity concentration and its contribution (in weight percent) of the final aggregate blend for that specific concrete recipe. Thus, these final weighted aggregate analyses of gamma energy values are not analyzed values from STUK, but calculated at CBI. These aggregate samples are denoted $\mathbf{A}_{\mathbf{w}}$ (Table 2).

The sampling procedures of the concrete specimens and final sample portions sent for analysis are described in Döse et al. (2014), but are summarized here. Two out of four sawn portions of the concrete specimens $(300 \mathrm{~mm} \times 300 \mathrm{~mm}$ ) were chosen from the large concrete specimens $(1500 \mathrm{~mm} \times 1500 \mathrm{~mm})$. The quadratic samples were randomly chosen from the larger concrete specimens, and cut in half. One half from each quadratic block, once again randomly picked, was selected for crushing. After crushing, a final portion of the crushed material, containing the particle size fraction of 0-6 mm was sent for analysis after splitting of the sample to reach a weight of $6-8 \mathrm{~kg}$. Multiple analyses of each concrete portion were conducted to check the repeatability of the results.

\subsection{Density measurements of aggregates and concrete}

The density of the aggregates was measured for particle size fractions of $4-8 \mathrm{~mm}$ or $8-16 \mathrm{~mm}$ using the standard procedure according to SS-EN 1097-6 (2013). The density was then applied for all particle size fractions related to each "Id" in Table 2.

The density of the concrete was measured approximately six months after casting, using a quadratic block of each concrete specimen of $300 \times 300 \times 150 \mathrm{~mm}$ or $300 \times 300 \times 200 \mathrm{~mm}$ in size. In order to calculate the density, a calibrated scale to determine the weight $(\mathrm{kg})$ and a ruler to determine the volume $\left(\mathrm{m}^{3}\right)$ were used. The density of the cement was measured by use of a helium gas pycnometer (SP methodology 1338).

\subsection{Concrete and its constituents}

The concrete specimens normally included mixes of two or three aggregate particle size fractions. In one case, only one particle size fraction (0-18 mm) was used. A standard CEM II/A-LL $42.5 \mathrm{R}$ (Portland clinker cement with a portion of 6-20\% limestone and rapid hardening properties) from the Skövde cement factory was used as binder. The component of air was assumed to be approximately $1.5 \%$ in volume. A cement-content of $350 \mathrm{~kg} / \mathrm{m}^{3}$ was applied. For concrete used for dwellings a minimum strength class of at least C30/37 was set as the primary target (Table F.1, SS-EN 206). Using the current water-cement weight ratio at mixing a strength development of approximately $55 \mathrm{MPa}$ (28 days) could be anticipated for the concrete specimens. An additive (SIKA sikament 56) was used to obtain a slump of approximately $100 \mathrm{~mm}$ for good workability of the concrete. An example of a basic recipe of the concrete is presented in Table 1. 
Table 1

Quantities of the different constituents in one concrete specimen. The weight \% is of aggregate only, whereas the mass per volume is of the concrete. The quantities of the constituents are similar in all concrete samples.

\begin{tabular}{lll}
\hline Constituents & Weight proportion of aggregate $(\%)$ & Mass per volume concrete $\left(\mathrm{kg} / \mathrm{m}^{3}\right)$ \\
\hline Cement, CEM II & & 350 \\
Crushed, aggregate, $0-8 \mathrm{~mm}$ & 42 & 770 \\
Crushed, aggregate $8-16 \mathrm{~mm}$ & 58 & 1064 \\
Water (at $\left.20{ }^{\circ} \mathrm{C}\right)$ & & 158 \\
Air $(1.5 \%$ by volume) & & 0.02 \\
Additives (Sikament 56$)$ & & 1.0 \\
Total & & 2343 \\
\hline
\end{tabular}

\section{Results}

Table 2 shows the gamma spectrometric analyses for the aggregates, water, additive, cement and concrete. The thickness of the concrete castings and the density of the aggregates are also included in the Table. The type of method is indicated in the "sample type" column, where $\mathrm{A}=$ crushed aggregate, A$S=$ Aggregate, natural sand, $A_{\operatorname{mix}}=2-3$ aggregate particle size fractions combined according to the recipe and sent for analysis, $A_{w}=$ mean value (wt\%), calculated by CBI from single aggregate analysis and weighted due to each aggregates percentage (wt\%) of contribution in the concrete, $\mathrm{C}=$ concrete analyzed once, $\mathrm{C}_{\mathrm{m}}=$ concrete presented as a mean value from two or more analyses of the same crushed material. Generally, at least two gamma spectrometric analyses were performed for each concrete sample.

In Table 2, the activity concentrations of ${ }^{40} \mathrm{~K},{ }^{226} \mathrm{Ra}$, and ${ }^{232} \mathrm{Th}$ of aggregates and concretes (mean values) are presented. It also includes the calculation of their corresponding I-indices, the relative errors (uI/I-index). Fig. 1 presents the I-index values of each concrete analysis as a function of the mean value of aggregates $\left(A_{w}\right.$ or $A_{\text {mix }}$ ) constituting part of the concrete.

Finally, Fig. 2 presents the calculated mean value of the concretes (Table 2) when used in the dose-model by Hoffman (2014) as a function of the I-indices $\left(A_{w}\right.$ or $A_{\text {mix }}$ ) of aggregates.

The dose-model values are calculated from the numerical values of the activity concentrations of ${ }^{40} \mathrm{~K},{ }^{226} \mathrm{Ra}$ and ${ }^{232} \mathrm{Th}$ in the concrete. A density correction from the measured values of the concrete prisms presented in Table 2 has been done to $2350 \mathrm{~kg} / \mathrm{m}^{3}$, which is the recommended approach in RP 112 (1999). The calculated dose (mSv per year) assumes a concrete thickness of $200 \mathrm{~mm}$ and an annual time spent indoors by the resident of $7000 \mathrm{~h}(\sim 80 \%)$, which is analogous to the conditions presented in RP 112 (EC, 1999). The differences due to the varying densities of the concretes (Table 2) are for the samples investigated in the range of $\pm 0.01 \mathrm{mSv}$ per year. The regression analysis of the calculated values originating from concrete and aggregates in Figs. 1 and 2 both yield $R^{2}$ values close to 1 (excluding sample 4), meaning that the fraction of variations in the dependent variable $(y)$ can be well-explained by variations in the independent variable $(\mathrm{x})$ by the linear regression models (Garcia, 2010).

\section{Analysis and discussion}

The approach of the paper was to emphasize the differences in radiation dose between a construction/building material (concrete) and its constituents (e.g. aggregate). There are, however, some uncertainties that need to be addressed. Sample four (Id-number 4) showed a significantly higher thorium content as part of the concrete samples, than in the aggregates (Table 2, Fig. 1). The concrete samples analyses were repeated three times for the concrete specimen of $150 \mathrm{~mm}$ and twice for the concrete specimen of $200 \mathrm{~mm}$. Thus, the discrepancy is most likely related to aggregate sampling. This is likely due to the small portion of aggregates $(\sim 30 \mathrm{~kg}$ ) sampled from the large 900-1000 kg portions delivered by the producers. This has to be considered an anomaly, generating a non-representative result when correlating between aggregates, concrete and the dose model applied.

There was also uncertainty in the gamma spectrometric analysis with a median error of $8 \%$ (Klemola et al., 2010). Other factors of uncertainty are uneven distribution of aggregates within the portions of the concrete specimens chosen for analysis. By cutting a fairly large part out from the even larger concrete specimens combined with multiple analyses of the same concrete samples, this uncertainty should have been minimized. There may also be a small discrepancy due to splitting of samples from nearly $30 \mathrm{~kg}$ down to a portion of $6-8 \mathrm{~kg}$.

Analyzing each aggregate $\left(A_{w}\right)$, in contrast to blending the aggregates $\left(A_{\text {mix }}\right)$ also shows some variations in the content of the natural isotopes of ${ }^{40} \mathrm{~K},{ }^{226} \mathrm{Ra}$ and ${ }^{232} \mathrm{Th}$ between different particle size fractions from the same quarry. This shows the heterogeneity of the bedrock material, which often occurs within a quarry and which makes correct sampling of the material very important. Hence, numerous samples should if possible be evaluated to encompass the variation of natural radiation of the bedrock within a quarry.

The activity concentration $(\mathrm{Bq} / \mathrm{kg})$ within the end concrete product is controlled by each constituent's activity concentration (Bq/ $\mathrm{kg}$ ). In this study, approximately $16 \%$ (by weight) of the concrete is cement. The cement had a low content of the radioactivity (Table 2). Using the I-index, the contribution of radioactivity due to the input of cement was approximately $3 \%$, whilst an aggregate with a calculated I-index of 1 would contribute to $78 \%$ of the concrete's I-index. Consequently, in the final concrete product, a theoretical value of $0.81(0.03+0.78)$ instead of 1 in I-index of the concrete could be anticipated, yielding a reduction of approximately $19 \%$ in radiation dose, which was shown experimentally. This however, excludes input of radioactivity from water and additives, which is minor (Table 2).

\section{Concluding remarks}

Aggregates used in concrete and the concrete containing the aggregates were empirically examined by laboratory gamma ray spectrometry. The calculated $\mathrm{R}^{2}$-values of the regression analysis of Figs. 1 and 2, excluding sample 4, yield $R^{2}$-values $>0.95$, are interpreted as trustworthy correlations in the linear regression models.

Calculations of I-indices of the aggregates and their respective concrete mix show an overall approximate decrease of the gamma radiation by $16-19 \%$, when the aggregate is distributed in the concrete using the current recipe. The dose model by Hoffman (2014) implies a further spread between the I-index and the annual effective dose within a predefined room. If the aggregates used in the concrete have an I-index of 1 , a comparable annual effective dose of $\sim 0.65 \mathrm{mSv}$ per year is calculated for the resulting 
Table 2

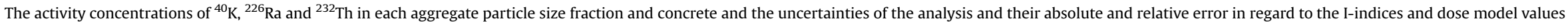
calculated. Included are also, the weight, thickness and density of the samples. "NS" denotes not specified.

\begin{tabular}{|c|c|c|c|c|c|c|c|c|c|c|c|c|c|c|c|c|c|}
\hline Bedrock & Id & $\begin{array}{l}\text { Sample } \\
\text { type }\end{array}$ & $\begin{array}{l}\text { Particle size fraction } \\
(\mathrm{mm})\end{array}$ & $\begin{array}{l}\text { Thickness } \\
(\mathrm{mm})\end{array}$ & $\begin{array}{l}\text { Weight } \\
(\%)\end{array}$ & $\begin{array}{l}\text { Density }(\mathrm{kg} / \\
\left.\mathrm{m}^{3}\right)\end{array}$ & $\mathrm{K}^{40}$ & $\mathrm{Ra}^{226}$ & $\mathrm{Th}^{232}$ & $\begin{array}{l}\text { No of } \\
\text { measurements }\end{array}$ & $\begin{array}{l}\mathrm{I}- \\
\text { index }\end{array}$ & $\mathrm{K}^{40}$ & $\mathrm{Ra}^{226}$ & $\mathrm{Th}^{232}$ & $\begin{array}{l}\text { Absolute error } \\
\left(\mathrm{u}_{\mathrm{I}}\right)\end{array}$ & $\begin{array}{l}\text { Relative error } \mathrm{u}_{\mathrm{l}} / \mathrm{I} \\
(\%)\end{array}$ & $\begin{array}{l}\text { Dose- } \\
\text { calculation }\end{array}$ \\
\hline & & & & & & & $\begin{array}{l}\text { Activi } \\
\text { conce } \\
\mathrm{kg} \text { ) }\end{array}$ & $\begin{array}{l}\text { ity } \\
\text { intratior }\end{array}$ & I (Bq/ & & & $\begin{array}{l}\text { Unce } \\
95 \% \\
\text { inter } \\
\text { Acti } \\
\text { conc } \\
\text { (Bq/l }\end{array}$ & $\begin{array}{l}\text { ertain } \\
\text { confic } \\
\text { rval ( } \\
\text { ivity } \\
\text { centra } \\
\text { (kg) }\end{array}$ & $\begin{array}{l}\text { ity - } \\
\text { dence } \\
\pm \text { ) } \\
\text { tion }\end{array}$ & & & mSv per year \\
\hline \multirow[t]{7}{*}{ Granitoid } & 1 & A & $0-8$ & & 57.8 & & 1445 & 285 & 195 & 1 & 2.41 & 130 & 59 & 18 & 0.22 & 9.12 & \\
\hline & & A & $8-16$ & & 42.2 & 2610 & 1270 & 250 & 190 & 1 & 2.21 & 100 & 41 & 15 & 0.16 & 7.22 & \\
\hline & & $A_{w}$ & & & & & 1371 & 270 & 193 & & 2.32 & 117 & 51 & 16 & 0.19 & 8.36 & \\
\hline & & c & & 150 & & & 1220 & 250 & 160 & 1 & 2.04 & 120 & 45 & 13 & 0.17 & 8.25 & \\
\hline & & C & & 150 & & & 1090 & 200 & 160 & 1 & 1.83 & 90 & 40 & 12 & 0.15 & 8.16 & \\
\hline & & C & & 150 & & & 1020 & 200 & 140 & 1 & 1.71 & 100 & 48 & 14 & 0.18 & 10.42 & \\
\hline & & $c_{m}$ & & 150 & & 2288 & 1110 & 217 & 153 & 3 & 1.86 & 103 & 44 & 13 & 0.17 & 8.88 & $1.85(1.84)$ \\
\hline \multirow{4}{*}{ Granitoid } & 2 & $\mathrm{~A}$ & $0-18$ & & 100 & 2610 & 1490 & 130 & 250 & 1 & 2.18 & 135 & 36 & 23 & 0.17 & 7.85 & \\
\hline & & C & & 150 & & & 1230 & 100 & 210 & 1 & 1.79 & 100 & 21 & 17 & 0.12 & 6.42 & \\
\hline & & C & & 150 & & & 1080 & 93 & 180 & 1 & 1.57 & 90 & 22 & 14 & 0.11 & 6.73 & \\
\hline & & $\mathrm{C}_{\mathrm{m}}$ & & 150 & & 2260 & 1155 & 97 & 195 & 2 & 1.68 & 95 & 22 & 16 & 0.11 & 6.55 & $1.55(1.54)$ \\
\hline \multirow[t]{5}{*}{ Granitoid } & 3 & $A_{\text {mix }}$ & $0-4$ & & $\begin{array}{l}54.9 \\
451\end{array}$ & 2640 & 1740 & 180 & 120 & 1 & 1.78 & 170 & 47 & 12 & 0.18 & 9.95 & \\
\hline & & C & $6-16$ & 150 & 45.1 & & 1460 & 150 & 100 & 1 & 1.49 & 150 & 31 & 10 & 0.13 & 8.42 & \\
\hline & & c & & 150 & & & 1430 & 130 & 99 & 1 & 1.41 & 140 & 27 & 8 & 0.11 & 7.76 & \\
\hline & & $c_{m}$ & & 150 & & 2338 & 1445 & 140 & 100 & 2 & 1.45 & 145 & 29 & 9 & 0.12 & 8.10 & $1.37(1.36)$ \\
\hline & & c & & 200 & & 2336 & 1410 & 140 & 98 & 1 & 1.43 & 140 & 28 & 10 & 0.12 & 8.11 & $1.35(1.35)$ \\
\hline \multirow[t]{11}{*}{ Granitoid/gneiss } & 4 & $A_{\text {mix }}$ & $0-2$ & & 28.1 & & 820 & 44 & 32 & 1 & 0.58 & 80 & 12 & 3 & 0.05 & 8.68 & \\
\hline & & & $2-4$ & & 24.4 & & & & & & & & & & & & \\
\hline & & A & $8-16$ & & 47.5 & 2760 & 720 & 37 & 30 & 1 & 0.51 & 60 & 8 & 2 & 0.04 & 6.94 & \\
\hline & & $A_{w}$ & & & & & 768 & 40 & 31 & & 0.54 & 70 & 10 & 3 & 0.04 & 7.82 & \\
\hline & & $\mathrm{C}$ & & 150 & & & 790 & 62 & 110 & 1 & 1.02 & 80 & 15 & 11 & 0.08 & 7.74 & \\
\hline & & c & & 150 & & & 690 & 48 & 97 & 1 & 0.88 & 70 & 12 & 10 & 0.07 & 7.79 & \\
\hline & & C & & 150 & & & 710 & 48 & 100 & 1 & 0.90 & 60 & 17 & 8 & 0.07 & 8.05 & \\
\hline & & $C_{m}$ & & 150 & & 2423 & 730 & 53 & 102 & 3 & 0.93 & 70 & 15 & 10 & 0.07 & 7.80 & $0.73(0.74)$ \\
\hline & & c & & 200 & & & 580 & 38 & 91 & 1 & 0.78 & 50 & 16 & 7 & 0.07 & 8.51 & \\
\hline & & c & & 200 & & & 800 & 56 & 100 & 1 & 0.95 & 80 & 18 & 11 & 0.09 & 8.98 & \\
\hline & & $c_{m}$ & & 200 & & 2407 & 690 & 47 & 96 & 2 & 0.86 & 65 & 17 & 9 & 0.08 & 8.74 & $0.66(0.66)$ \\
\hline Gneiss/ & 5 & $A_{\text {mix }}$ & $0-2$ & & 27.1 & 2620 & 1160 & 43 & 54 & & 0.80 & 120 & 12 & 5 & 0.06 & 7.73 & \\
\hline \multirow[t]{5}{*}{ metasedimentary } & & & $2-5$ & & 34.8 & & & & & & & & & & & & \\
\hline & & & $8-16$ & & 38.1 & & & & & & & & & & & & \\
\hline & & c & & 150 & & & 920 & 41 & 42 & 1 & 0.65 & 90 & 12 & 4 & 0.05 & 8.24 & \\
\hline & & $\mathrm{C}$ & & 150 & & & 890 & 35 & 43 & 1 & 0.63 & 70 & 11 & 4 & 0.05 & 7.61 & \\
\hline & & $C_{m}$ & & 150 & & 2310 & 905 & 38 & 43 & 2 & 0.64 & 80 & 12 & 4 & 0.05 & 7.93 & $0.43(0.43)$ \\
\hline Natural sand & 6 & A-S & $0-8$ & & 50 & 2620 & 880 & 22 & 18 & 1 & 0.46 & 70 & 13 & 2 & 0.05 & 11.00 & \\
\hline Gneiss/ & & A & $8-16$ & & 50 & 2670 & 1320 & 74 & 80 & 1 & 1.09 & 130 & 24 & 8 & 0.10 & 9.15 & \\
\hline \multirow[t]{4}{*}{ metasedimentary } & & $A_{w}$ & & & & & 1100 & 48 & 49 & & 0.77 & 100 & 19 & 5 & 0.07 & 9.64 & \\
\hline & & c & & 150 & & & 823 & 36 & 41 & 1 & 0.60 & 66 & 9 & 3 & 0.04 & 6.70 & \\
\hline & & C & & 150 & & & 910 & 40 & 43 & 1 & 0.65 & 90 & 17 & 4 & 0.07 & 10.30 & \\
\hline & & $c_{m}$ & & 150 & & 2327 & 867 & 38 & 42 & 2 & 0.63 & 78 & 13 & 4 & 0.05 & 8.55 & $0.41(0.41)$ \\
\hline \multirow[t]{7}{*}{ Gneiss } & $7 \mathrm{~A}$ & $A_{\text {mix }}$ & $0-8$ & & 52 & 2640 & 1060 & 19 & 44 & & 0.64 & 85 & 7 & 4 & 0.04 & 6.56 & \\
\hline & & & $8-16$ & & 48 & & & & & & & & & & & & \\
\hline & & C & & 150 & & & 1090 & 22 & 41 & 1 & 0.64 & 110 & 7 & 4 & 0.05 & 7.46 & \\
\hline & & C & & 150 & & & 1000 & 17 & 41 & 1 & 0.60 & 80 & 13 & 3 & 0.05 & 8.80 & \\
\hline & & $C_{m}$ & & 150 & & 2359 & 1045 & 20 & 41 & 2 & 0.62 & 95 & 10 & 4 & 0.05 & 7.91 & $0.39(0.39)$ \\
\hline & $7 \mathrm{~B}$ & $\mathrm{c}$ & & 150 & & & 1000 & 15 & 41 & 1 & 0.59 & 80 & 7 & 3 & 0.04 & 6.54 & \\
\hline & & C & & 150 & & & 1020 & 18 & 42 & 1 & 0.61 & 80 & 8 & 4 & 0.04 & 6.91 & \\
\hline
\end{tabular}




\begin{tabular}{|c|c|c|c|c|c|c|c|c|c|c|c|c|c|c|c|c|c|}
\hline Bedrock & Id & $\begin{array}{l}\text { Sample } \\
\text { type }\end{array}$ & $\begin{array}{l}\text { Particle size fraction } \\
(\mathrm{mm})\end{array}$ & $\begin{array}{l}\text { Thickness } \\
(\mathrm{mm})\end{array}$ & $\begin{array}{l}\text { Weight } \\
\text { (\%) }\end{array}$ & $\begin{array}{l}\text { Density }(\mathrm{kg} / \\
\left.\mathrm{m}^{3}\right)\end{array}$ & $\mathrm{K}^{40}$ & $\mathrm{Ra}^{226}$ & $\mathrm{Th}^{232}$ & $\begin{array}{l}\text { No of } \\
\text { measurements }\end{array}$ & $\begin{array}{l}\text { I- } \\
\text { index }\end{array}$ & $\mathrm{K}^{40}$ & & $\mathrm{Th}^{232}$ & $\begin{array}{l}\text { Absolute error } \\
\left(\mathrm{u}_{\mathrm{I}}\right)\end{array}$ & $\begin{array}{l}\text { Relative error } \mathrm{u}_{\mathrm{l}} / \mathrm{I} \\
(\%)\end{array}$ & $\begin{array}{l}\text { Dose- } \\
\text { calculation }\end{array}$ \\
\hline & & $C_{m}$ & & 150 & & 2287 & 1010 & 16 & 42 & 2 & 0.60 & 80 & 7 & 4 & 0.04 & 6.72 & $0.37(0.36)$ \\
\hline \multirow[t]{6}{*}{ Granitoid/gneiss } & 8 & A & $0-8$ & & 58 & & 830 & 51 & 36 & 1 & 0.63 & 80 & 17 & 4 & 0.07 & 10.49 & \\
\hline & & A & $8-16$ & & 42 & 2670 & 800 & 34 & 29 & 1 & 0.53 & 80 & 10 & 3 & 0.05 & 8.62 & \\
\hline & & $A_{w}$ & & & & & 817 & 44 & 33 & & 0.58 & 80 & 14 & 4 & 0.06 & 9.82 & \\
\hline & & & & 150 & & & 690 & 38 & 29 & 1 & 0.50 & 70 & 17 & 3 & 0.06 & 12.58 & \\
\hline & & & & 150 & & & 610 & 29 & 26 & 1 & 0.43 & 60 & 7 & 3 & 0.03 & 7.71 & \\
\hline & & $C_{m}$ & & 150 & & 2355 & 650 & 33 & 28 & 2 & 0.47 & 65 & 12 & 3 & 0.05 & 10.19 & $0.24(0.24)$ \\
\hline \multirow[t]{4}{*}{ Granitoid } & 9 & $A_{\text {mix }}$ & $0-2$ & & 25.7 & 2670 & 620 & 44 & 25 & 1 & 0.48 & 62 & 11 & 3 & 0.04 & 9.34 & \\
\hline & & & $2-5$ & & 26.8 & & & & & & & & & & & & \\
\hline & & & $4-16$ & & 47.5 & & & & & & & & & & & & \\
\hline & & $\mathrm{C}$ & & 150 & & 2417 & 539 & 33 & 26 & 1 & 0.42 & 48 & 11 & 3 & 0.04 & 10.07 & $0.19(0.19)$ \\
\hline \multirow[t]{3}{*}{ Gabbro } & 10 & $A_{\text {mix }}$ & $0-8$ & & 55.9 & 2960 & 287 & 7 & 7 & 1 & 0.15 & 29 & 4 & 1 & 0.02 & 11.09 & \\
\hline & & & $8-16$ & & 44.1 & & & & & & & & & & & & \\
\hline & & C & & 150 & & 2562 & 261 & 8 & 7 & 1 & 0.15 & 21 & 4 & 1 & 0.02 & 10.06 & $-0.12(-0.12)$ \\
\hline \multirow[t]{3}{*}{ Granitoid } & 11 & $A_{\text {mix }}$ & $0-4$ & & 54.9 & 2850 & 470 & 21 & 21 & 1 & 0.33 & 40 & 11 & 2 & 0.04 & 12.14 & \\
\hline & & & $\begin{array}{l}4-8 \\
8-16\end{array}$ & & $\begin{array}{l}4.1 \\
41\end{array}$ & & & & & & & & & & & & \\
\hline & & C & & 200 & & 2589 & 390 & 18 & 16 & 1 & 0.27 & 40 & 9 & 2 & 0.04 & 12.95 & $0.02(0.02)$ \\
\hline \multirow[t]{10}{*}{ Granitoid } & 12 & A & $0-8$ & & 50 & & 1175 & 170 & 78 & 1 & 1.35 & 105 & 41 & 7 & 0.15 & 10.78 & \\
\hline & & A & $8-16$ & & 50 & 2670 & 1185 & 73 & 60 & 1 & 0.94 & 105 & 15 & 6 & 0.07 & 7.13 & \\
\hline & & $A_{w}$ & & & & & 1180 & 122 & 69 & & 1.14 & 105 & 28 & 6 & 0.10 & 9.14 & \\
\hline & & C & & 200 & & & 970 & 120 & 74 & 1 & 1.09 & 80 & 18 & 6 & 0.07 & 6.60 & \\
\hline & & $C$ & & 200 & & & 940 & 110 & 72 & 1 & 1.04 & 80 & 24 & 6 & 0.09 & 8.61 & \\
\hline & & $C_{m}$ & & 200 & & 2418 & 955 & 115 & 73 & 2 & 1.07 & 80 & 21 & 6 & 0.08 & 7.56 & $0.87(0.87)$ \\
\hline & & C & & 150 & & & 1030 & 120 & 73 & 1 & 1.11 & 100 & 26 & 7 & 0.10 & 8.95 & \\
\hline & & C & & 150 & & & 930 & 100 & 72 & 1 & 1.00 & 80 & 18 & 6 & 0.07 & 7.19 & \\
\hline & & C & & 150 & & & 890 & 99 & 65 & 1 & 0.95 & 90 & 24 & 7 & 0.09 & 9.70 & \\
\hline & & $\mathrm{C}_{\mathrm{m}}$ & & 150 & & 2359 & 925 & 105 & 70 & 3 & 1.00 & 83 & 21 & 6 & 0.08 & 8.11 & $0.94(0.94)$ \\
\hline Cement & & Powder & & & & 3080 & 320 & 16 & 16 & 1 & 0.24 & 30 & 5 & 1 & 0.02 & 9.04 & \\
\hline Water & & Liquid & & & & $\begin{array}{l}\sim 998 \text { (at } \\
\left.20^{\circ} \mathrm{C}\right)\end{array}$ & $<1.57$ & $<1.11$ & $<0.27$ & 1 & & NS & & & 0.07 & 8.24 & \\
\hline Additive (SIKA 56) & & Liquid & & & & $\begin{array}{l}1080 \text { (at } \\
\left.20^{\circ} \mathrm{C}\right)\end{array}$ & $<2.14$ & $<2.40$ & $<0.46$ & 1 & & & & & & & \\
\hline
\end{tabular}




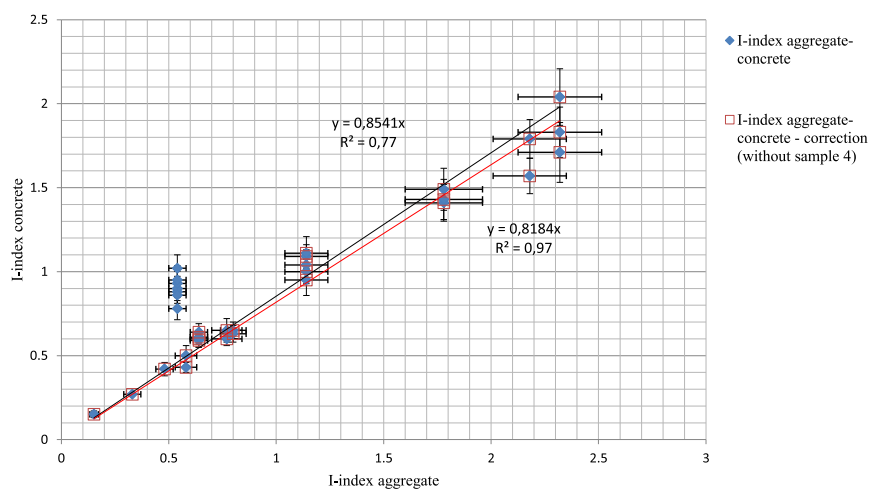

Fig. 1. I-indices of concrete as a function of the mean I-indices of aggregates $\left(A_{\text {mix }}\right.$ or $\left.A_{w}\right)$ constituting part of the concrete.

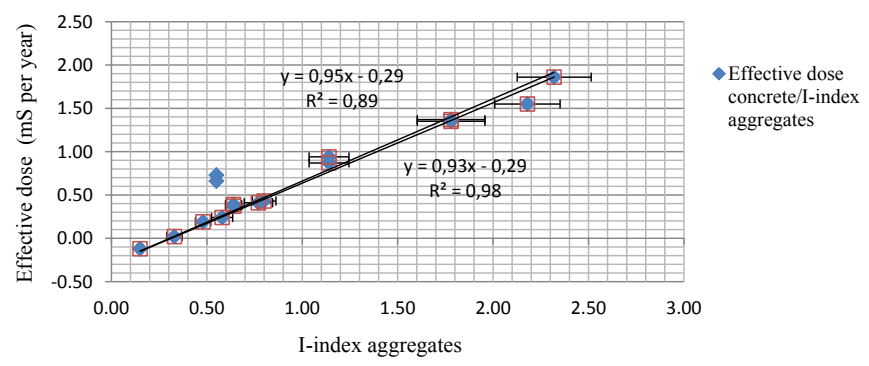

Fig. 2. The effective dose (in $\mathrm{mSv}$ ) of the concrete samples using the dose model as a function of the mean I-indices of aggregates $\left(A_{\text {mix }}\right.$ or $\left.A_{w}\right)$.

concrete. The density of the examined concretes varied between 2260 and $2560 \mathrm{~kg} / \mathrm{m}^{3}$. The difference in the effective dose when corrected to $2350 \mathrm{~kg} / \mathrm{m}^{3}$ as proposed by the dose model had almost no implication to the effective dose within a room of $3 \mathrm{~m} \times 4 \mathrm{~m} \times 2.5 \mathrm{~m}$ with solid concrete walls.

The present empirical study has shown that an aggregate yielding an I-index of 1 or slightly above, will, when included in a concrete product yield a considerably lower annual effective dose than $1 \mathrm{mSv}$ per year in a stipulated model room. The cause is mainly related to a dilution effect caused by the addition of cement.

\section{Acknowledgments}

Special thanks to the Swedish Consortium for Financing Fundamental Research in the Concrete Area, who has partly funded and supported the research and the project using empirical data. Specially thanks also to some native English speaking colleagues at Borås, who have assisted in the first critical review of the document in English with great patience. Finally, the authors wish to express their utmost appreciations to the colleagues at CBI Borås, who have contributed with strong efforts to cast all the concrete specimens necessary during this project.

\section{References}

Almgren, S., Isaksson, M., Barregard, L., 2008. Gamma radiation doses to people living in Western Sweden. J. Environ. Radioact. 99, 394-403.

Andersson, P., Carlsson, M., Falk, R., Hubbard, L., Leitz, W., Mjönes, L., Möre, H. Nyblom, L., Söderman, A.-L., Yuen Lasson, K., Åkerblom, G., Öhlén, E., 2007. Radiation Environment in Sweden (Strålmiljön i Sverige). in Swedish. SSI rapport 2007:02.

Beretka, I., Matthew, P.I., 1985. Natural radioactivity of Australian building materials. Waste and byproducts. Health Phys. 48.
CE, 2011. Regulation (EU) No 305/2011 Of The European Parliament and of the Council laying down harmonised conditions for the marketing of construction products and repealing Council Directive 89/106/EEC (2011). Off. J. Eur. U. N. 88, $5-43$.

CE, 2014. COUNCIL DIRECTIVE 2013/59/EURATOM of 5 December 2013 laying down basic safety standards for protection against the dangers arising from exposure to ionising radiation, and repealing Directives 89/618/Euratom, 90/641/Euratom, 96/29/Euratom, 97/43/Euratom and 2003/122/Euratom. Off. J. Eur. U. N. 13, $1-73$.

Döse, M., Silfwerbrand, J., Jelinek, C., Trägårdh, J., 2014. Evaluation of the I-index by use of a portable hand-held spectrometer and laboratory methods - a risk assessment of Swedish concrete by use of different crushed aggregates. Mineralproduksjon 5, 35-53.

EC, 1996. Directorate-general Environment, Nuclear Safety and Civil Protection. In: Enhanced Radioactivity of Building Materials. Radiat Prot 96.

EC, 1999. Directorate-general Environment, Nuclear Safety and Civil Protection. In: Radiological Protection Principles Concerning the Natural Radioactivity of Building Material. Radiat Prot 112.

Erlandsson, B., Isaksson, M., 2006. Urban dose rates at Gävle, Göteborg and Lund. J. Environ. Radioact. 85, 241-246.

Garcia, E., 2010. A Tutorial on Correlation Coefficients. http://web.simmons.edu/ benoit/lis642/a-tutorial-on-correlation-coefficients.pdf.

Hagberg, N., Möre, H., 1978. Activity Level in Aggregates for Concrete Production in Sweden (Aktivitetshalt i ballastmaterial för betongtillverkning i Sverige). In Swedish, SSI: 1978-029. Statens Strålskyddsinstitut. Stockholm, Sweden.

Hoffman, B., 2014. A simple dose assessment tool from construction products. In: Proc.. Of the EU-NORM2 Conference, Prague June 17-19. http://eunormprague2014.cz/.

Klemola, S., Leppänen, A.P., Mattila, A., Renvall, T., 2010. Gamma spectrometric sample measurements at STUK laboratories. In: Proceedings - Third European IRPA Congress, 14-18 June 2010. Nord Soc radiat Prot, Helsinki, Finland.

Koblinger, L., 1978. Calculation of exposure rates from gamma sources in walls of buildings. Health Phys. 34, 459-463.

Krisiuk, E.M., Tarasov, S.I., Shamov, V.P., Shalak, N.I., Lisachenko, E.P., Gomelsky, 1971. A Study on Radioactivity in Building Materials. Res Inst Radiat Hyg, Leningrad, Russia.

Maringer, F.J., Baumgartner, A., Rechberger, F., Seidel, C., Steetka, M., 2013. Activity measurements and effective dose modeling of natural radionuclides in building materials. App Radiat. Isot. 81, 279-283.

Markkanen, 1995. Radiation Dose Assessments for Materials with Elevated Natural Radioactivity. STUK B STO-32. Department of Radiation Safety. Finnish Centre For Radiation And Nuclear Safety, 38. Helsinki, Finland.

Mjönes, L., 1986. Gamma radiation in swedish dwellings. Radiat. Prot. Dosim. 15 (2), $131-140$.

Möre, H., 1985. Radioactive Substances in Building Materials (Radioaktiva ämnen i byggnadsmaterial). in Swedish, SSI-repp. 85-08: 56. Stockholm, Sweden.

Nuccetelli, C., Leonardi, F., Trevise, R., 2015. A new accurate and flexible index to assess the contribution of building materials to indoor gamma exposure. J. Environ. Radioact. 143, 70-75. SP-metod 1338(1997). Evaluation of density by automated helium gas pycnometre - Accupyc 1340, 6.

SS-EN 1097-6, 2013. Tests for Mechanical and Physical Properties of Aggregates. In: Part 6: Determination of Particle Density and Water Absorption, Swedish Standard Institute, Stockholm, Sweden, p. 49.

SS-EN 1766, 2000. Products and Systems for the Protection and Repair of Concrete Structures. In: Test Methods - Reference Concretes for Testing, Swedish Standard Institute, Stockholm, Sweden, p. 13.

SS-EN 206, 2013. Concrete - Specification, Performance, Production and Conformity. Swedish Standard Institute, Stockholm, Sweden, p. 93.

SS-EN 932-1, 1997. Tests for General Properties of Aggregates. In: Part 1: Methods for Sampling, Swedish Standard Institute, Stockholm, Sweden, p. 25.

SS-EN 932-2, 1999. Tests for General Properties of Aggregates. In: Part 2: Methods for Reducing Laboratory Samples, Swedish Standard Institute, Stockholm, Sweden, p. 15.

Stoulos, S., Manolopoulou, M., Papastefanou, C., 2003. Assessment of natural radiation exposure and radon exhalation from building materials in Greece. J. Environ. Radioact. 69, 225-240.

Stranden, E., 1976. Some aspects of radioactivity of building materials. Phys. Norvegia $8,167-173$.

Technical report - TC 351/WG 3 N 136. N 0586, 2014. Dose Assessment of Emitted Gamma Radiation for Consultation. Draft TR 00351020, p. 40.

Technical Specification TC 351/WG 3. N099, 2012. Draft TS 00351014 Construction Products - Assessment of Release of Dangerous Substances - Determination of Activity Concentrations of Radium-226, Thorium-232 and Potassium-40 in Construction Products Using Gamma-ray Spectrometry, p. 37.

Trevisi, R., Nuccetelli, C., Risica, S., 2013. Screening tools to limit the use of building materials with enhanced/elevated levels of natural radioactivity: analysis and application of index criteria. Constr. Build. Mat. 49, 448-454.

Trevisi, R., Risica, S., D’allesandro, M., Paradiso, D., Nuccetelli, C., 2012. Natural radioactivity in building materials in the European Union: a database and an estimate of radiological significance. J Environm Radioact 105, 11-20. 